\title{
NATIONAL BUREAU OF STANDARDS REPORT 2045
}

- Ventilating System for the Univac Computer

\author{
by \\ O. N. McDorman \\ Paul R. Achenbach
}

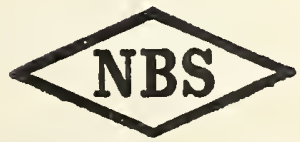

U. S. DEPARTMENT OF COMMERCE NATIONAL BUREAU OF STANDARDS 


\section{U. S. DEPARTMENT OF COMMERCE Charles Sawyer, Secretary}

\section{NATIONAL BUREAU OF STANDARDS}

A. V. Astin, Director

\section{THE NATIONAL BUREAU OF STANDARDS}

The scope of activities of the National Bureau of Standards is suggested in the following listing of the divisions and sections engaged in technical work. In general, each section is engaged in special. ized research, development, and engineering in the field indicated by its title. A brief description of the activities, and of the resultant reports and publications, appears on the inside of the back cover of this report.

Electricity. Resistance Measurements. Inductance and Capacitance. Electrical Instruments. Magnetic Measurements. Applied Electricity. Electrochemistry.

Optics and Metrology. Photometry and Colorimetry. Optical Instruments. Photographic Technology. Length. Gage.

Heat and Power. Temperature Measurements. Thermodynamics. Cryogenics. Engines and Lubrication. Engine Fuels. Cryogenic Engineering.

Atomic and Radiation Physics. Spectroscopy. Radiometry. Mass Spectrometry. Solid State Physics. Electron Physics. Atomic Physics. Neutron Measurements. Infrared Spectroscopy. Nuclear Physics. Radioactivity. X-Rays. Betatron. Nucleonic Instrumentation. Radio. logical Equipment. Atomic Energy Commission Instruments Branch.

Chemistry. Organic Coatings. Surface Chemistry. Organic Chemistry. Analytical Chemistry. Inorganic Chenistry. Electrodeposition. Gas Chemistry. Physical Chemistry. Thermochemistry. Spectrochemistry. Pure Substances.

Mechanics. Sound. Mechanical Instruments. Aerodynamics. Engineering Mechanics. Hy. draulics. Mass. Capacity, Density, and Fluid Meters.

Organic and Fibrous Materials. Rubber. Textiles. Paper. Leather. Testing and Specifcations. Polymer Structure. Organic Plastics. Dental Research.

Metallurgy. Thermal Metallurgy. Chemical Metallurgy. Mechanical Metallurgy. Corrosion.

Mineral Products. Porcelain and Pottery. Glass. Refractories. Enameled Metals. Con. creting Materials. Constitution and Microstructure. Chemistry of Mineral Products.

Building Technology. Structural Engineering. Fire Protection. Heating and Air Conditioning. Floor, Roof, and Wall Coverings. Codes and Specifications.

Applied Mathematics. Numerical Analysis. Computation. Statistical Engineering. Machine Development.

Electronics. Engineering Electronics. Electron Tubes. Electronic Computers. Electronic Instrumentation.

Radio Propagation. Upper Atmosphere Research. Ionospheric Research. Regular Propaga. tion Services. Frequency Utilization Research. Tropospheric Propagation Research. High Frequency Standards. Microwave Standards.

Ordnance Development.

Electromechanical Ordnance. and development in advanced ordnance. Activities include

Electronic Ordnance. basic and applied research, engineering, pilot production, field testing, and evaluation of a wide variety of ordnance matériel. Special skills and facilities of other NBS divisions also contribute to this program. The activity is sponsored by the Department of Defense.

Missile Development. Missile research and development: engineering, dynamics, intelligence, instrumentation, evaluation. Combustion in jet engines. These activities are sponsored by the Department of Defense.

- Office of Basic Instrumentation

- Office of Weights and Measures. 


\section{NATIONAL BUREAU OF STANDARDS REPORT NBS PROJECT \\ NBS REPORT}

$1203-30-5790$

November 4, 1952

2045
Tests of the Ventilating System for the Univac Computer

by

O. N. McDorman

Paul R. Achenbach

Heating and Air Conditioning Section Building Technology Division

The publlcation, ref unless permission is 25, D. C. Such pert cally prepared if the

\author{
for \\ Machine Tabulation Division \\ Bureau of the Census
}

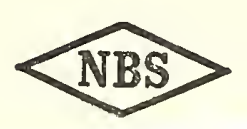

Approved for public release by the Director of the National Institute of Standards and Technology (NIST) on October 9, 2015.

In part, Is prohlblted itandards, Washington eport has been specifiiport for Its own use. 

The Ventilating System of the Univac Computer

by

O. N. McDorman

P. R. Achenbach

Abstract

Tests were made of the ventilating system of the Univac Computer for the Census Bureau to evaluate the temperatures and ventilation rates of three complete units when in operation. From these results it was found that with an cutside temperature of $105^{\circ} \mathrm{F}$ the installation would require a minimum of $20,000 \mathrm{cfm}$ of ventilating air to prevent shutdowns by the temperature limit devices. The imnortance of other factors were evaluated and their influence on nerformance was analyzed. Recommendations on the design and installation of the svstem at Suitland, Maryland, are presented. Precautions arainst recirculation, duct resistance and discomfort of operating personnel were included.

After a careful consideration of the several designs factors it was recommended that the system be designed for a total of $30,000 \mathrm{cfm}$ of ventilating air. The central comnuter was to be supplied with $22,500 \mathrm{cfm}$ and the power supply with 7,500 cfm。

\section{INTRODUCTION}

In accordance with a request of the Census Bureau and the Electronic Computer Section of the National Bureau of Standards tests were made to determine the operating temperatures and ventilation rates of three computers manufactured by the Eckert-Nauchly Division of Remington Rand, Inc. Two units, designed as numbers 1 and 3, were located at the plant of the manufacturer in Philadelphia, Pennsvlvania. The other unit, number 2 , was located at the Pentagon, Arlington, Virginia. These three units are the first three commercial models of this computer produced by the manufacturer.

Some interruptions in the operation of both of the computer units in Philadelphia had occurred during this past summer as a result of excessive onerating temperatures. The Heating and Air Conditioning Section of the National Bureau of Standards was requested to analyze tre ventilat in systems of these units to determine the cause of the interruptions and to recommend either a ventilating system 

or an air conditioning system for unit number 1 when it is installed in the Census Bureau at Snitland, Maryland in the near future.

\section{DESCRIPTION OF TYE UNJVAC CON'PUTER}

The Univac computer consisted of four major elements: the central computer cabinet, the power supply, the servomechanism unit, and the control panel. In studying the ventilatino system only the central computer cabinet and the power supply were of interest. The central computer cabinet was a laroe metal enclosure annroximately 14 feet long, \& feet wide, and 7 feet high enclosing a great many electronic elements which used electric eneroy and generated heat. Access to the inside components was orovided by a door on one of the long, sides and various groups of electronic elements were accessible from the outside through three doors, one above the other, on each of the 13 bays into which the cabinet was divided.

The power supply cabinet measured about 4 by 6 by 7 feet high, was accessible from the outside on three sides, and contained a door for access to the interior components on the fourth side. Each of the three bays contained rectifiers or other heat generating equipment arranged in 5 sections, one above tre other. Diagrammatic sketches of the central computer cabinet and power supply are show in Fig. I with the various bays numbered for convenience in identifying where certain observations were made.

\section{THERMOSTATIC PROTECTION}

A temperature-sensitive element of the bimetallicdisc tyre was located in the air stream at the top of each of the 13 bays in the centryl computer cabinet and the 3 bays in the power supply as a protective device against excessive temperature. These devices were temperature limit switches all connected in series in a control circuit so that an excessive terrerature sensed by any one of the 16 elements would interrunt the power to both units until trat element was cooled below the tripping temperature and manually reset. These temperature limits, also, interrupted the power to the ventilating fans for fire protection. A temrerature limit of $135^{\circ} \mathrm{F}$ had been set as the maximum safe temperature for the ecuipment and it was some of these protective devices that had caused stoppages of Units 1 and 3 in Philadelphia during hot, weather. 



\section{VENTILATION}

Ventilation air was drawn from the outside througk filters, and then forced by centrifugal blowers to a plenum under the floor beneath the central computer and power supply cabinets. Air from the plenum passed upward through the electronic equipment in the power supply cabinet and was exhausted outdoors by an overhead duct system. In the central computer cabiret the air passed upward through passages between tre electron tubes and other electronic devices and the inside of tre exterior doors on the 13 bays of that cabinet with a small portion of the air being diverted throurh the interior of the cabinet proner. The air stream nassed directly over, more or less depending on the exact location of certain elements, the thermostatic limit switch at the top of each bay. The Fentacon unit, number 2 , also employed an exhaust blower since both the incoming and outgoing ducts were cuite long and there might be some difficulty in controlling the air conditioning of that area if a single blower were used. Unjts 1 and 3 used separate blowers and separate duct systems for central computer and power supply whereas unit 2 used a common supnly and exhaust duct for both components.

At the Fhiladelnhia installations both the air intake and air discharge ducts terminated in an elbow opening downward just outside the wall of the building above a parking lot. The discharge duct was directly above the intake and the distance between the tro was about 10 or 12 feet. At the Fentagon installation the intake and discharge openings were at ground level about 10 or 12 feet apart facing East and North respectively.

\section{TEST APPARATUS AND PROCEDURE}

Temperatures were measured by means of a Brown Electronick Potentiometer Pyrometer Single Point Precision Indicator. Conper-constantan thermocouples were affixed with transparent tape around each of the 16 thermal elements. Any effect of ambient air on the temperature indication was minimized by havin" the junction and the adjacent 3 or 4 inches of wire firmly in contact, with the metal supporting member. Additional temperature observations were made of intake ard exhaust, air for both corronents. A more detailed study was made of the temperatures within the power supply cabinet at the Pentapon installation. 1 total of 24 thermocouples were suspended in air one inch above selected rectifiers and transformers. A 24-point selector switch was used to connect anv one thermocornle to the indicator. Temperature values were recorded usually at 15 minute intervals until a steady state condition was reached. 

Air velocity measurements were made with a revolving vane ancmometer at all installaticns. The cross sectional area of the intake duct was divided irto numorous elerentary areas of aproximately enual size and tre air velocity was measurec at the center of each srall area. The air velocities at each station were averaged mechanically over a perioc of one minute which eliminated erroneous readings due to pulsations. At the fentaron additional readings were taken by the use of a Pitot tuhe and inclined gauge. All observations were made directly in the duct system inasmuch as preliminary measurerent,s indicated that readings taken rear the fijter banks ould be difficult to evaluate. Values reported were obtained with all inspection and access doors closed.

\section{TEST RESUITS}

Table I show's the temperatures observed at the 16 temperature limit devices. The bays are designated in a clockwise manner, number one beins to the left of the main entrance door when entering, as shown in Fig. 1. Table 2 shows the temperature of the inlet and outlet air, their difference, the maximum rise in air temperature at any location, the cuantity of ventilating air to the two components, and trejr total. Also srom are the calculated values of heat dissipation.

An examination of Table 1 shows that the temperature rise in the several bays of the central computer differed widelv. The temperature rise cbserved in the hottest bay was about $2-1 / 2$ to 3 times as great as that in the coolest bay, and the averace temperature rise for all 13 bays was only about half the maximum temperature rise through the hottest bay. The three hottest bays in Unit 1 were 7 , 9 and 10; in Writ 2 they were 7,8 and 9 ; and in Unit 3 they were 7,8 and 9. An examination 01 these bays indicated that bays 7 and contained a considerably preater number of electron tubes than the othors. Thus there was probably more heat to be dissinated in these bays and at the same time more obstruction to the air flow.

The temperature rises in the three bays of the nower supnly cabinet were more nearly uniform than for the central computer.

No specific reason was established why the average temperature rise and the maximum temperature rise was greater for Unit 2 than for Unit 1 when the observed total air circulation rates were nearly the same. However, there 

were some leaks in the wooden duct on the intake side of the blower of Unit 1 beyond the place where the air velocity measurements were made, whereas metal duct with tight joints was used in Unit 2. Thus the actual air circulation rate through the central comouter of Unit 1 may have been appreciably greater than the observed value.

A more detailed analysis of the temperatures which existed within the power supply cabinet was made upon Unit 2. With an entering air temperature of $80^{\circ} \mathrm{F}$, temperatures of $130.0^{\circ} \mathrm{F}$ and $127.5^{\circ} \mathrm{F}$ were recorded one inch above the rectifiers located in the upper level of the bottom section in bay No. 3. The highest value observed in bay No. I was $116.0^{\circ} \mathrm{F}$. In the four sections directly above in bay No. 3 temperatures of $106.0^{\circ} \mathrm{F}, 107.0^{\circ} \mathrm{F}, 114.0^{\circ} \mathrm{F}$ and $104.0^{\circ} \mathrm{F}$ were recorded. Corresponding temperatures to the left of the entrance door in bay No. I were $91.0^{\circ} \mathrm{F}$, $111.0^{\circ} \mathrm{F}, 101.0^{\circ} \mathrm{F}$, and $103.8^{\circ} \mathrm{F}$.

Some recirculation of air between outlet and inlet was observed in units 1 and 3. By a comparison of the temperatures of the intake air and air over the parking lot several feet from the intake and supply openings it was determined that the inlet air was 7 to 10 dexrees warmer than the outdoor air. of course, recirculation would adversely affect the computer performance in hot weather。

An approximation of the heat absorbed in the various units can be obtained by using the temperature rise of the air and the quantity of air circulated. The results of this computation are shown in Table 2 both as units of heat and units of electrical power. - It was stated by the operating personnel that approximately $125 \mathrm{KV}$ of power was used by each unit. The computed values for Units I and 3 were appreciably lower than this value and they were 20 to $30 \mathrm{KW}$ lower than the computed value for Unjt 2 . The computed power consumptions for the central computer of Units 1 and 3 and for the power supply of Unit 1 were appreciably less than the correspondino values for Unit 2 . These variations are attributed to the greater air leakage into the intake duct systems and the greater outrard leakage around the doors or the several bays of the cabinets for Units 1 and 3 than for Unit 2. Another contributing factor for the power supply of Unit 1 was the exceptionally small intake opening which would tend to increase the air leakao even more. 



\section{DISCUSSION AND CONCLUSIONS}

Based on Weather Bureau data for Washington, D.C., it was decided that the ventilation rate for the installation at Suitland, Maryland, should be based on a maximum outdoor temperature of $105^{\circ} \mathrm{F}$. Assuming that the temperature limit devices in the computer would be set to shut the unit down at a temperature of $135^{\circ} \mathrm{F}$, the maximum temperature rise that could be tolerated in any bay would be $30^{\circ} \mathrm{F}$.

It is believed that the data obtained on Unit 2 were more accurate than for Units 1 and 3 because the duct leakage was less, the ducts were longer and a better measuring station could be found, and more time was available for the observations. Tables 1 and 2 show that a maximum temperature rise of $35.5^{\circ} \mathrm{F}$ was observed in bay No. 9 in Unit 2 for an air circulation rate of 14,550 cfm. It can be assumed that the product of the ventilating air rate and the temperature rise would be a constant.

That is $14550 \times 35.5=517,000=K$

Then for a maximum rise of $30^{\circ} \mathrm{F}$ the required air circulation rate would be

$$
\mathrm{V}=\frac{517,000}{30}=17000 \mathrm{cfm}
$$

Similarly for the power supply cabinet

$$
\begin{aligned}
& \mathrm{K}_{I}=3850 \times 23=89000 \\
& \mathrm{~V}_{I}=\frac{89000}{30}=3000 \mathrm{cfm}
\end{aligned}
$$

These ventilation rates would be the minimum which would give satisfactory operation during the hottest weather and they provide no margin of safety. A factor of safety should be incorporated in the selection of the design ventilation rates to allow for the following contingencies:

(a) Errors in correctly evaluating duct friction

(b) Excessive dirt on the filters and leaves and paper on the intake screen

(c) Recirculation between outlet and inlet due to duct location or wind direction

(d) Loss of air from cabinets due to doors or panels being left open for inspection or service. 

It is recommended, therefore, that the ventilation rate for the central computer be made about one-third larger than the minimum value or $22500 \mathrm{cfm}$.

The decision about how much ventilation air should be rrovided for the power supply is confused by the failure of a number of selenium rectifiers in Unit 2 and the locai temperature rise of $50^{\circ} \mathrm{F}$ observed near one of these units in Unit 2. Based on the maximum temperature observed on one of the limit swjtches in the power supply of Unit 2, the minjmum ventilation rate would be $3000 \mathrm{cfm}$ as previously shown. However, considering trat the temperature rise of the air near one of the rectifiers was $50^{\circ} \mathrm{F}$ and that the rectifier itself could easily have been 10 or 20 degrees warmer than the downstream air, rectifier temperatures of the order of $170^{\circ} \mathrm{F}$ seem entirely possible for the design inlet ventilating, air temperature of $105^{\circ} \mathrm{F}$. The available literaturea, on selenjum rectifiers indicates that they should be derated as much as 40 percent in output voltage and current when operated at temperatures on the order of $170^{\circ} \mathrm{F}$. By doubling the ventila.tion rate on the power supply of Unit 2 the temperatures of the hottest rectifier could probably be reduced 20 to 25 degrees. Probably the temperature rise of this one rectifier could be reduced by a modification of the air passages inside the power supply to direct more air over it.

Considering the sensitivity of the selemium rectifiers to high temperatures it is recommended that 7500 cfm of ventilating air be provided for the power surply.

Ir our opinion, the cooling of the Univac computers can be done adequately at less cost and without introducing the mechanical problems of refrigeration equipment by the use of the proper quantities of ventilating air. The difficulties with the present installation stem primarily from insufficient ventilating air, inadequate duct system, and recirculation for Units 1 and 3 , and from insufficient ventilating air and dirty intake screen and filters on Unit 2 .

a. Metal Rectifiers, by H.K.Henisch(1949) Oxford University Press, London.

b. Selenium kectifiers, by S.Niciejewski, Radio and Television News, Oct.1952。 

The following factors should be iven careful consideration in the desion of the ventilating system for the installation at suitland:

(a) Care must be taken to provert the reated exhaust air from reentering tre air intake. Fossible solutions would he to terminate the supp? y and exhaust ducts on oprosite sides of a wing of the buizdine or face the discharge and intake openings in opposite directions. The intake should probably be uptind from the exhaust for the nrevailing summer wind direction.

(b) The intake for ventilation air should be high enough above oround level so it will. not collect leaves, scrap paper, and trash. This was an important source of trouble on Unit 2 at the Pentason.

(c) A reserve supply of air filters should be kept on hand and adecuate maintenance of. filters should be assured. The blowers should be selected to deliver the recuired ventilating air with a reasonabie dirt load on the filters (say 0.5 inch water gage pressure drop across the fjlters).

(a) Duct restrictions and 180 degree bends should be avoided in the intake and exhaust ducts.

(e) A check test to determine the amount of air provided should be made after installation is completed and at stated intervals during use of the computers.

Consideration should be given to the installation of a 16-point temperature recorder for a continuous record of the temperatures at important locaticis to warn of impending shutdowns before they occur. Such an instrument would cost approximately 2,000 。

A manual reset of the control circuit on the ventilating fans that would permit starting the fans to cool the Injvac after it was determined that no fire existed in the eruinment, would shorten shutdown periods that djd occur for any reason. An interlocking device should be used on this marual reset so the main control circuit would again he the nrimary control when the computer was in oreration. 

It was shown in Table 1 that several of the bays in the central computer operated at temperatures well above the average. Designers of the Univac computer should give consideration to regrouping of the electric components to attain more uniform heat generation in the several bays or provide more ventilating air for the hotter bays by baffles or scoops in the sunnly plenum or redesign of the air passares in these bays. Considerably less ventilating air could be used if the heat dissipation in the several bays were balanced.

Cabinet doors with less air leakage would greatly aid in promoting the comfort of the operating personnel especially if a single blower is used to force air through the ventilating system. Locatins the control panel and the servomechanism unit in a room adiacent to the central computer cabinet and the power supply cabinet would greatly enhance the comfort of the operators and reduce the amount of comfort air conditioning required if that is contemplated. 

TEMPERATURES OF PROTECTIVE DEVICES $\mathrm{ON}$ UNIVAC COMPUTERS, ${ }^{\circ} \mathrm{F}$

\begin{tabular}{|c|c|c|c|c|c|c|}
\hline Bay & \multicolumn{3}{|c|}{$\begin{array}{c}\text { Central Computer } \\
\text { Unit No. }\end{array}$} & \multicolumn{3}{|c|}{$\begin{array}{c}\text { Power Supply } \\
\text { Unit No. }\end{array}$} \\
\hline No. & 1 & 2 & 3 & 1 & 2 & 3 \\
\hline 1 & 97.9 & 103.9 & 99.0 & 92.0 & 97.1 & 91.1 \\
\hline 2 & 97.2 & 107.3 & 99.8 & 92.2 & 103.1 & 92.1 \\
\hline 3 & 96.0 & 101.0 & 100.2 & 96.2 & 102.2 & 96.0 \\
\hline 4 & 96.5 & 102.0 & 100.0 & & & \\
\hline 5 & 98.3 & 102.9 & 98.0 & & & \\
\hline 6 & 101.0 & 106.5 & 103.4 & & & \\
\hline 7 & 113.3 & 113.0 & 110.0 & & & \\
\hline 8 & 108.1 & 114.0 & 106.0 & & & \\
\hline 9 & 102.0 & 115.5 & 104.9 & & & \\
\hline 10 & 108.2 & 106.8 & 91.9 & & & \\
\hline 11 & 104.0 & 107.1 & 92.0 & & & \\
\hline 12 & 95.0 & 100.0 & 97.9 & & & \\
\hline 13 & 96.1 & 95.0 & 99.0 & & & \\
\hline rage & 104.6 & 105.8 & 100.2 & 93.5 & 100.8 & 93.1 \\
\hline Temr & 82.0 & 80.0 & 85.0 & 82.0 & 80.0 & 85.0 \\
\hline
\end{tabular}





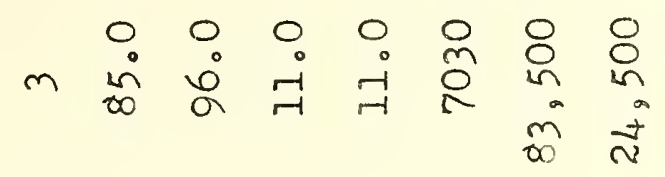

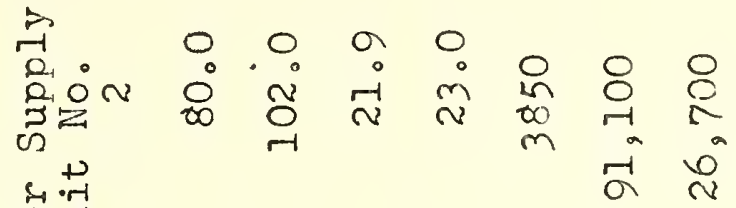

点苾

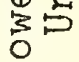

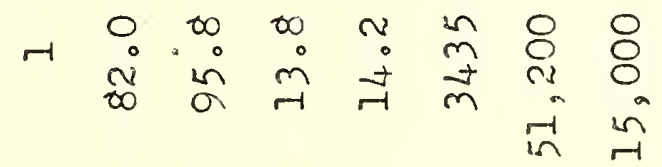

I

艺

0
-1

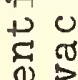

vi $>$

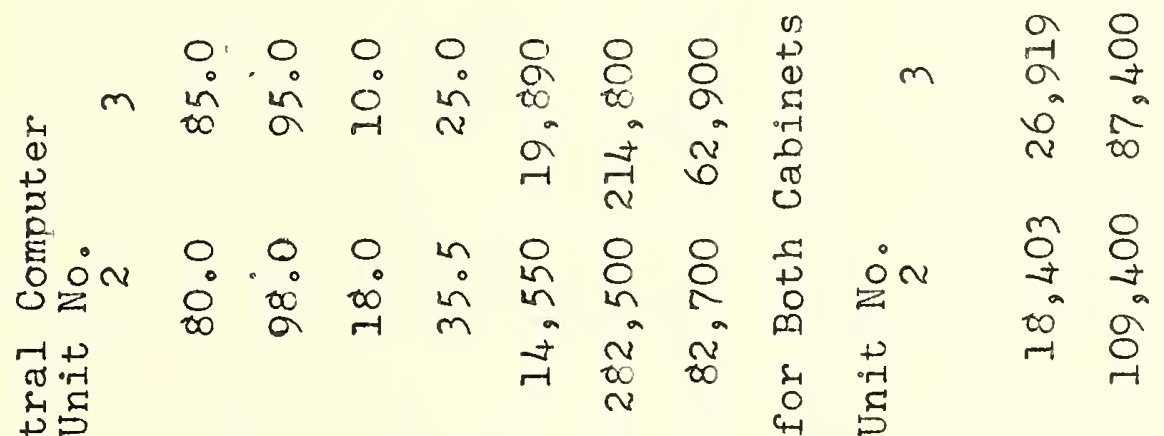

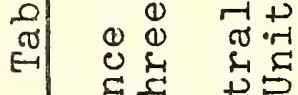

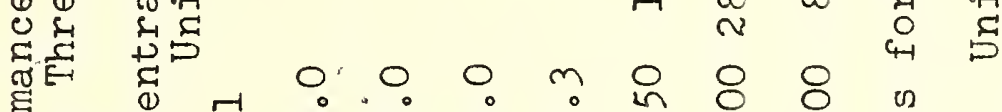

\&

0 車

क्ष 5

(1)

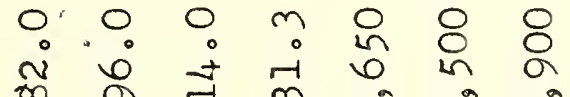

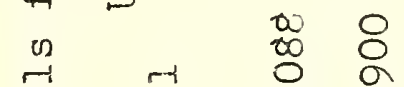

品

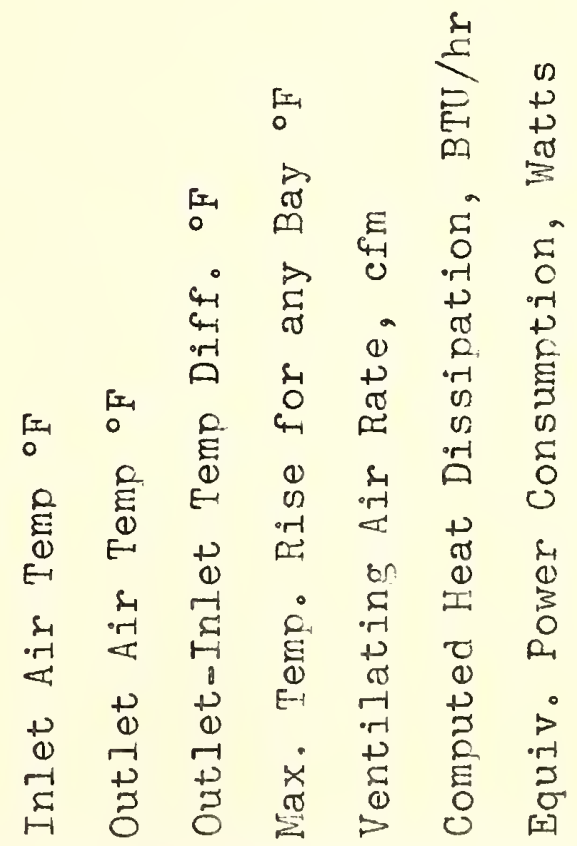

os

$\stackrel{0}{+}$

$\pm$

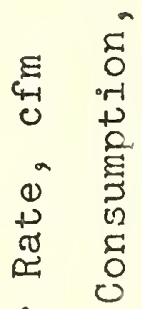

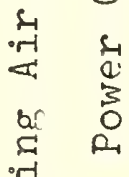

कै

त +

䓵 

DIMENSIONAL

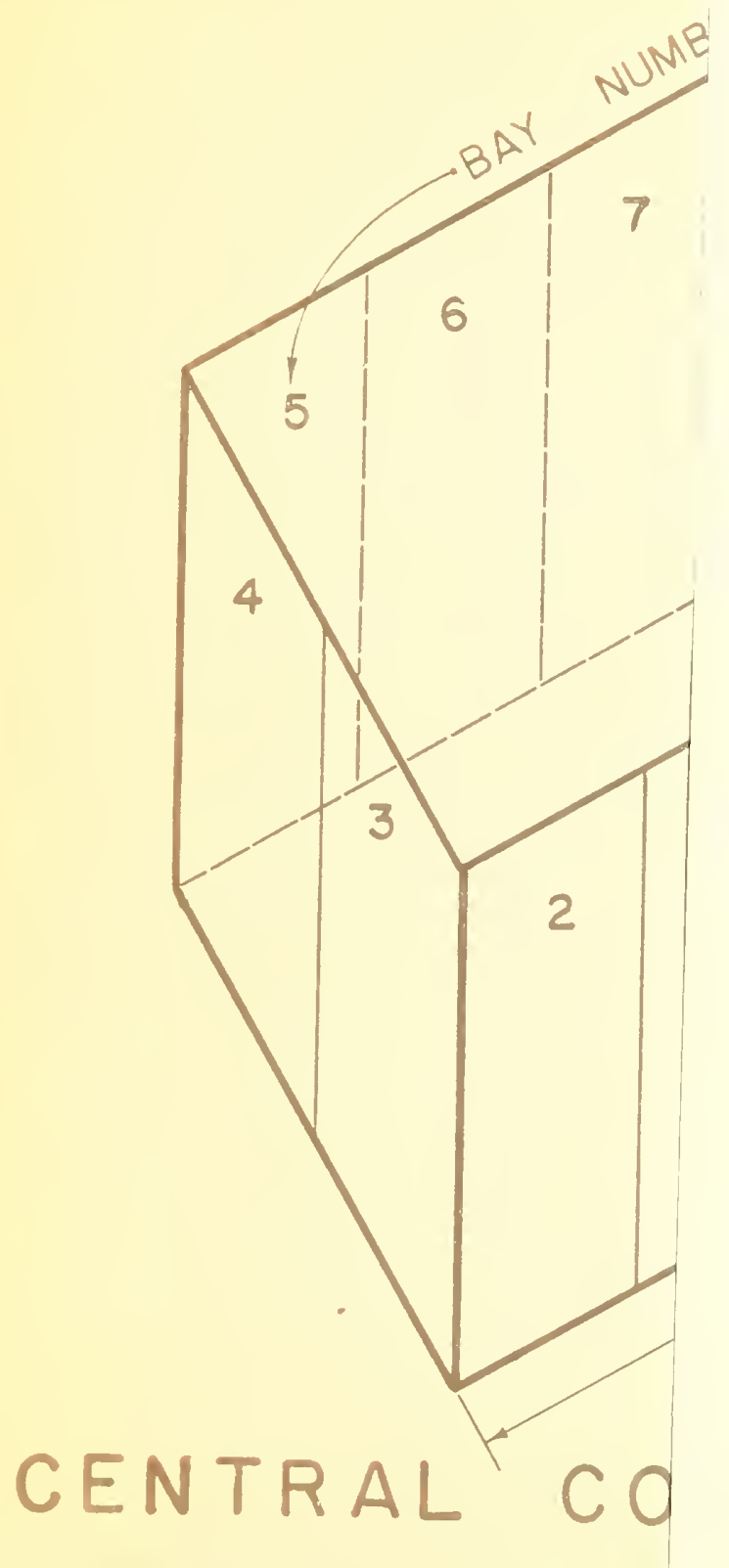



DIMENSIONAL DIAGRAM - COMPUTER CABINETS

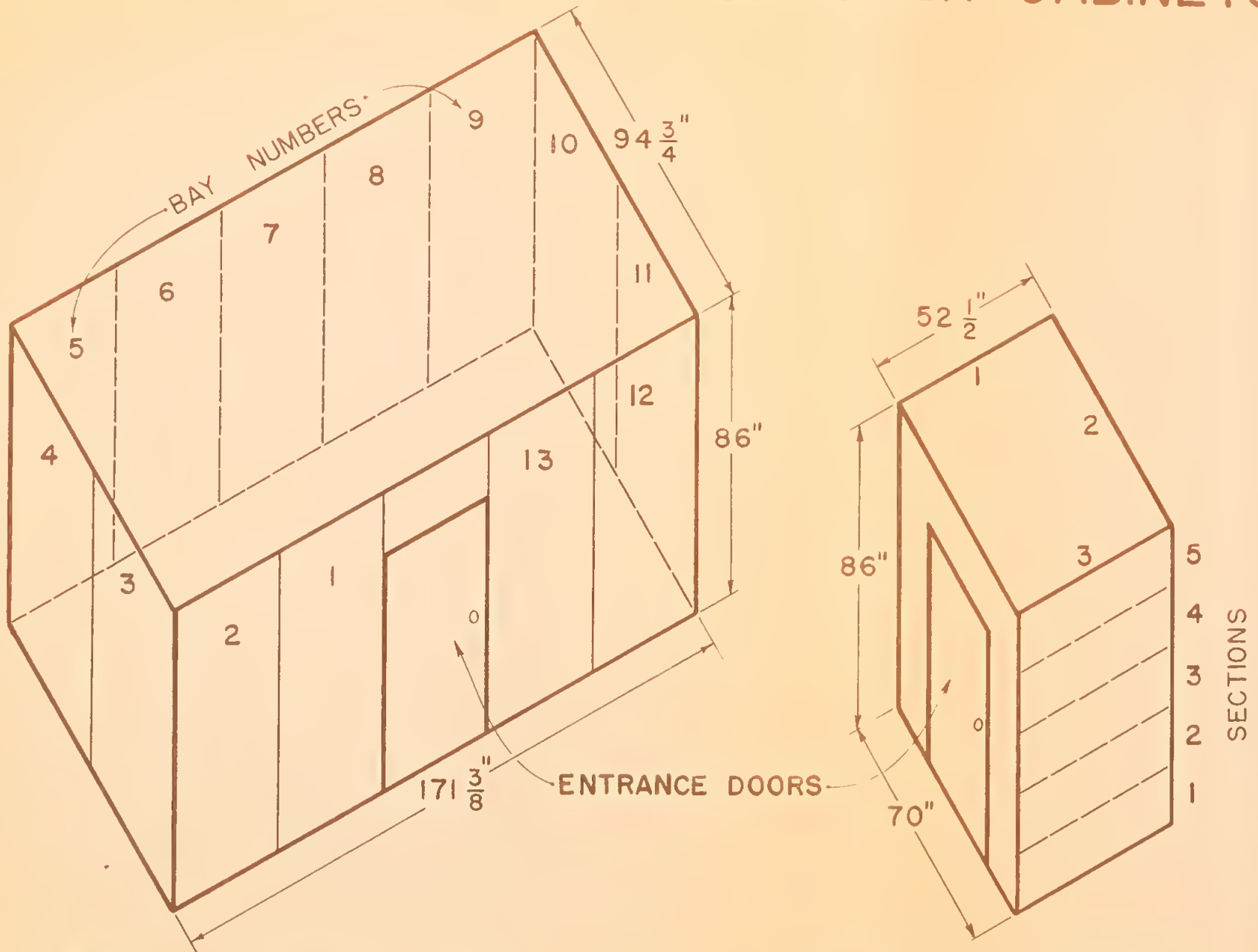

CENTRAL COMPUTER

Fig. I 



\section{THE NATIONAL BUREAU OF STANDARDS}

\section{Functions and Activities}

The functions of the National Bureau of Standards are set forth in the Act of Congress, March 3, 1901, as amended by Congress in Public Law 619, 1950. These include the development and maintenance of the national standards of measurement and the provision of means and methods for making measurements consistent with these standards; the determination of physical constants and properties of materials; the development of methods and instruments for testing materials, devices, and structures; advisory services to Government Agencies on scientific and technical problems; invention and development of devices to serve special needs of the Government; and the development of standard practices, codes, and specifications. The work includes basic and applied research, development, engineering, instrumentation, testing, evaluation, calibration services and various consultation and information services. A major portion of the Bureau's work is performed for other Government Agencies, particularly the Department of Defense and the Atomic Energy Commission. The scope of activities is suggested by the listing of divisions and sections on the inside of the front cover.

\section{Reports and Publications}

The results of the Bureau's work take the form of either actual equipment and devices or published papers and reports. Reports are issued to the sponsoring agency of a particular project or program. Published papers appear either in the Bureau's own series of publications or in the journals of professional and scientific societies. The Bureau itself publishes three monthly periodicals, available from the Government Printing Office: The Journal of Research, which presents complete papers reporting technical investigations; the Technical News Bulletin, which presents summary and preliminary reports on work in progress; and Basic Radio Propagation Predictions, which provides data for determining the best frequencies to use for radio communications throughout the world. There are also five series of nonperiodical publications: The Applied Mathematics Series, Circulars, Handbooks, Building Materials and Structures Reports, and Miscellaneous Publications.

Information on the Bureau's publications can be found in NBS Circular 460 , Publications of the National Bureau of Standards (\$1.00). Information on calibration services and fees can be found in NBS Circular 483, Testing by the National Bureau of Standards (25 cents). Both are available from the Government Printing Office. Inquiries regarding the Bureau's reports and publications should be addressed to the Office of Scientific Publications, National Bureau of Standards, Washington 25, D. C. 
